\title{
Benefits and Costs of the USA Coal Research, Development, and Demonstration Program
}

\author{
Roger H. Bezdek
}

\section{ABSTRACT}

This paper estimates the costs, impacts, and benefits of the U.S. Department of Energy (DOE) coal RD\&D program, 1976 - 2019. We provide detailed estimates by technology (in 2019 dollars) of the DOE coal RD\&D budget and find that program funding priorities have changed substantially over this period. We estimate that the benefits of the DOE coal RD\&D program through 2019 - \$236.7 billion (2019 dollars) - far exceed the costs -- $\$ 28.6$ billion (2019 dollars). This implies a benefit-cost (B-C) ratio of greater than 8-to-1, which is impressive. The number of jobs created over the period 2000-2019 - 1.6 million - is large, and the local job impacts are especially relevant at present. Recommendations for further research are provided and include the proper methodology for evaluating RD\&D programs and the necessity for comparing the results reported here with B-C estimates for other energy and related technologies.

Keywords: $\mathrm{CO}_{2}$ emissions abatement $\mathrm{R} \& \mathrm{D}$ programs, coal research programs; energy $R \& D$; job impacts of energy programs; $R \& D$ benefits and costs.

\section{INTRODUCTION}

There is currently intense interest and debate in the USA and elsewhere concerning energy and environmental research, development, and demonstration (RD\&D) programs, especially concerning fossil fuels - in particular coal. However, over the past five decades the U.S. Department of Energy (DOE) has expended nearly $\$ 30$ billion (2019 dollars) in coal RD\&D funds and the impacts of these expenditures have not been comprehensively estimated, assessed, and evaluated. Here we remedy this lack of knowledge by estimating in detail, in constant 2019 dollars, the technologies funded and the impacts and benefits of these expenditures and compare these to the cost of the RD\&D.

\section{REVIEW OF PREVIOUS STUdIES}

We reviewed relevant reports and studies over the past two decades in the existing body of literature on the economic and jobs impacts and the costs and benefits of the DOE coal RD\&D program. These are summarized in Table I. Most of this research found substantial benefits to the DOE coal RD\&D program, for example:

- The U.S. General Accountancy Office - perhaps the most respected and skeptical critic of federal programs - has repeatedly found the DOE Clean Coal Technology (CCT) program to be "exemplary
Published Online: July 22, 2021

ISSN: $2736-5506$

DOI : 10.24018 /ejenergy.2021.1.2.12

Dr Roger H. Bezdek*

Management Information Services, Inc. (e-mail: rbezdek@misi-net.com)

*Corresponding Author and well managed." [1].

- The National Research Council found that "The Coal R\&D program was one of DOE's most successful." [2].

- MISI found that the return on investment (ROI) to DOE from the coal RD\&D program is favorable and estimated an ROI of more than 13. [3].

\section{THE DOE COAL RD\&D BUDGET}

Over the past six decades, DOE has funded a substantial coal RD\&D program, including RD\&D for coal production, resource assessment, mining techniques, mining health and safety, coal utilization, coal liquefaction and gasification, clean coal technologies, carbon capture, utilization, and storage (CCUS), fuel cells, advanced technologies, Magnetohydrodynamics, pollution control and abatement, and other programs [4]. MISI estimated the detailed DOE coal RD\&D program expenditures from 1976 through 2020 and converted them to constant 2019 dollars using the implicit price deflator [5].

Fig. 1 shows the history of the DOE coal RD\&D budget from 1976 through 2020 and illustrates the trajectory of RD\&D spending over the past five decades. It shows that over the period, the cumulative budget totaled $\$ 29.12$ billion (2019 dollars), but the distribution of expenditures was very uneven [6]. Funding peaked in 1981 and then declined drastically. Funding in 2020 real terms was about equal to funding in 1983. 
Fig. 2 identifies the major program beneficiaries over the period 1976-2020 and show that:

- Coal Liquefaction received the most funding: $\$ 4.85$ billion $-17 \%$ of the total RD\&D budget.

- Coal Gasification received the second highest level of funding: $\$ 4.67$ billion $-13 \%$ of the total.

- CCUS received the third highest level of funding: $\$ 2.49$ billion $-8.6 \%$ of the total

- Advanced Research and Technology development received the fourth highest level of funding: $\$ 2.46$ billion $-8.4 \%$ of the total.

- Coal Liquefaction and Coal Gasification combined received a total of $\$ 8.5$ billion - nearly $30 \%$ of the total RD\&D expenditures.

- Four major programs which have not been funded for the past quarter century - Coal Liquefaction, Coal Gasification, Magnetohydrodynamics, and Mining RD\&D - were among the top ten funded and combined received $\$ 11.6$ billion $-40 \%$ of the total RD\&D budget.

Table II identifies the major programs funded in 1980, 1990, 2000, 2010, and 2020 and illustrates the substantial change in priorities of the RD\&D program over the past five decades.

The research thus provides detailed estimates by technology and budget category (in constant 2019 dollars) of the DOE coal RD\&D budget 1976-2020. This database is invaluable for a variety of uses and has not heretofore been available [7].

TABLE I: PREVIOUS STUDIES OF THE COSTS AND IMPACTS OF THE DOE COAL RD\&D PROGRAM

\begin{tabular}{|c|c|c|}
\hline date & Author & Major Finding \\
\hline 2001 & NETL [27] & $\begin{array}{l}\text { DOE's coal RD\&D yielded significant benefits, important technological options, and significant } \\
\text { additions to the stock of engineering and scientific knowledge. }\end{array}$ \\
\hline 2001 & NRC [28] & $\begin{array}{l}\text { Concluded that DOE coal RD\&D programs over the period 1978-1999 produced economic } \\
\text { benefits, options for the future, and knowledge benefits, and that the net realized economic } \\
\text { benefits exceeded the DOE investment. }\end{array}$ \\
\hline 2001 & GAO [29] & $\begin{array}{l}\text { Assessed the DOE Clean Coal Technology (CCT) program and found it to be an exemplary, } \\
\text { well-managed program that is providing substantial benefits. }\end{array}$ \\
\hline 2002 & NETL [30] & $\begin{array}{l}\text { Advanced DOE coal electricity generating technologies developed will result in lower electricity } \\
\text { prices and will reduce the national average price of electricity. }\end{array}$ \\
\hline 2004 & $\begin{array}{l}\text { DOE, EPRI, } \\
\text { and CURC } \\
{[31]}\end{array}$ & $\begin{array}{l}\text { Estimated the savings and environmental benefits of DOE's CCT program and found them to be } \\
\text { substantial. }\end{array}$ \\
\hline 2005 & $\begin{array}{l}\text { National } \\
\text { Research } \\
\text { Council [32] }\end{array}$ & $\begin{array}{l}\text { Developed and tested a methodology for assessing prospective benefits of DOE coal RD\&D } \\
\text { programs. }\end{array}$ \\
\hline 2006 & NETL [33] & Forecast sales and benefits of DOE's Clean Coal Technology Demonstration Program (CCTDP). \\
\hline 2007 & $\begin{array}{l}\text { NETL, } \\
\text { CMU, and } \\
\text { WVU [34] }\end{array}$ & $\begin{array}{l}\text { Assessed economic and environmental impacts of NETL on Pennsylvania and West Virginia } \\
\text { from NETL sites located in Pittsburgh, PA and Morgantown, WVA. }\end{array}$ \\
\hline 2009 & MISI [35] & $\begin{array}{l}\text { Analyzed the return on investment (ROI) of DOE's CCT program for the period 2000-2020 to be } \\
\text { 13. }\end{array}$ \\
\hline 2009 & NETL [36] & $\begin{array}{l}\text { Assessed the state and national level impacts of the NETL facilities located in Pennsylvania, } \\
\text { West Virginia, and Oregon [37]. }\end{array}$ \\
\hline 2009 & BBC [38] & $\begin{array}{l}\text { Estimated job and economic benefits from the deployment of advanced coal-fueled electric } \\
\text { generation using carbon capture and storage technologies. }\end{array}$ \\
\hline 2013 & DOE [39] & $\begin{array}{l}\text { Found that coal RD\&D increased domestic energy supplies and security, lowered costs, } \\
\text { improved efficiencies, and enhanced environmental protection. }\end{array}$ \\
\hline 2013 & MISI [40] & $\begin{array}{l}\text { Estimated economic and jobs impacts of a U.S.-wide coal power plant efficiency improvement } \\
\text { program. }\end{array}$ \\
\hline 2015 & NCC [41] & Assessed the benefits and accomplishments of the DOE CCUS program. \\
\hline 2017 & $\mathrm{UCS}[42]$ & $\begin{array}{l}\text { Identified major reasons why Congress should maintain support for federal energy } R \& D \\
\text { programs. }\end{array}$ \\
\hline 2018 & NETL & $\begin{array}{l}\text { Conducted an economic analysis using an input-output (I-O) model to quantify the laboratory's } \\
\text { economic impacts on the United States in } 2018 \text { [43]. }\end{array}$ \\
\hline 2019 & $\begin{array}{l}\text { LTI and } \\
\text { MISI [44] }\end{array}$ & $\begin{array}{l}\text { Estimated the economic and jobs benefits to Colorado of adding CCUS to the Comanche } \\
\text { Generating Station and transporting } \mathrm{CO} 2 \text { for use in enhance oil recovery (EOR). }\end{array}$ \\
\hline 2020 & LTI [45] & $\begin{array}{l}\text { Assessed the economic impact and carbon dioxide (CO2) emissions reductions of retrofitting } \\
\text { CCUS on Wyoming's coal power plants. }\end{array}$ \\
\hline
\end{tabular}

Source: Management Information Services, Inc.

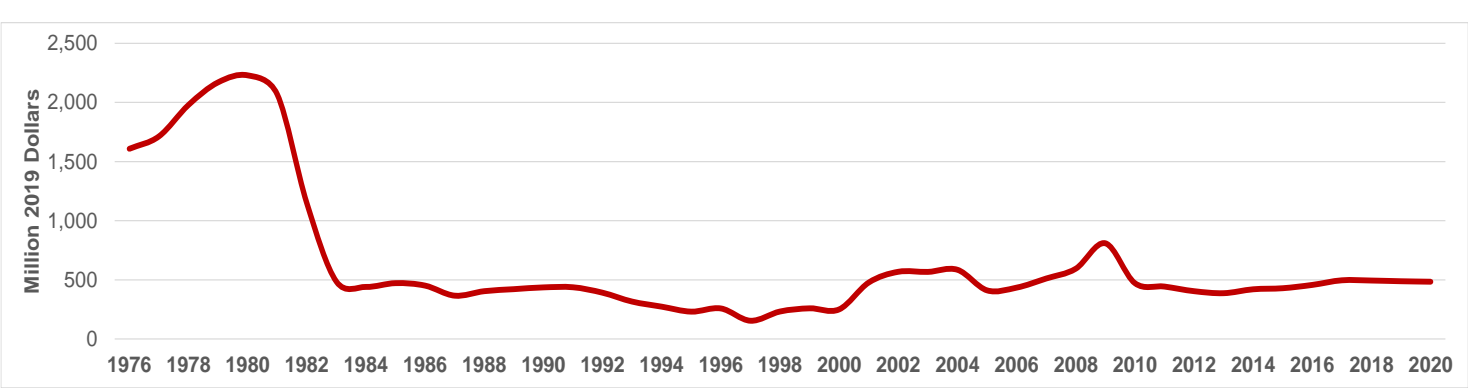

Fig. 1. U.S. DOE Coal RD\&D Expenditures, $1976-2020$.

*1976 transition quarter (TQ) funding included in year 1976 budget.

Source: U.S. Department of Energy and Management Information Services, Inc. 


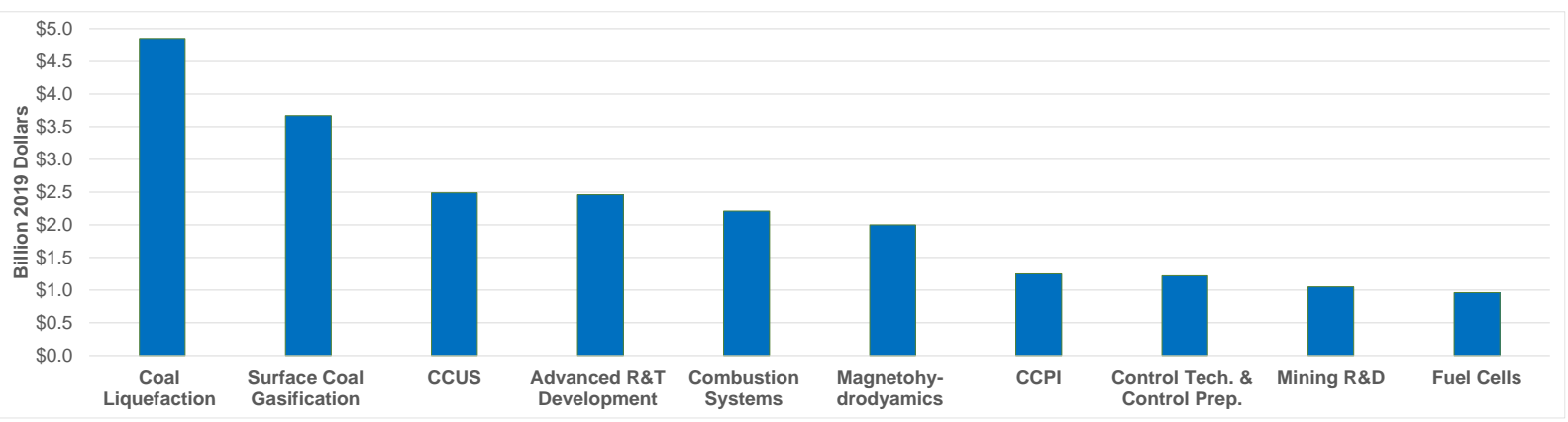

Fig. 2. Major Programs of U.S. DOE Coal RD\&D Expenditures, 1976-2020.

Source: U.S. Department of Energy and Management Information Services, Inc.

TABLE II: MAJOR PROGRAMS OF U.S. DOE COAL RD\&D EXPENDITURES, 1980, 1990, 2000, 2010, 2020 (MILLIONS OF 2019 DOLLARS)

\begin{tabular}{|c|c|c|c|c|c|c|c|c|c|}
\hline \multicolumn{2}{|c|}{1980} & \multicolumn{2}{|c|}{1990} & \multicolumn{2}{|c|}{2000} & \multicolumn{2}{|c|}{2010} & \multicolumn{2}{|c|}{2020} \\
\hline Program & Funding & Program & Funding & Program & Funding & Program & Funding & Program & Funding \\
\hline $\begin{array}{c}\text { Advanced R\&T } \\
\text { Develop. }\end{array}$ & 175 & $\begin{array}{l}\text { Control Tech. } \\
\& \text { Coal Prep. }\end{array}$ & 107 & $\begin{array}{l}\text { Advanced } \\
\text { R\&T } \\
\text { Develop. }\end{array}$ & 33 & $\begin{array}{c}\text { Innovations } \\
\text { for Existing } \\
\text { Plants }\end{array}$ & 61 & $\begin{array}{c}\text { Advanced } \\
\text { Energy } \\
\text { Systems }\end{array}$ & 148 \\
\hline $\begin{array}{c}\text { Coal } \\
\text { Liquefaction }\end{array}$ & 620 & $\begin{array}{c}\text { Advanced } \\
\text { R\&T Develop. }\end{array}$ & 47 & $\begin{array}{l}\text { Indirectly } \\
\text { Fired Cycle }\end{array}$ & 10 & $\begin{array}{l}\text { Advanced } \\
\text { IGCC }\end{array}$ & 73 & $\begin{array}{l}\text { Cross Cutting } \\
\text { Research }\end{array}$ & 48 \\
\hline $\begin{array}{l}\text { Combustion } \\
\text { Systems }\end{array}$ & 217 & $\begin{array}{c}\text { Coal } \\
\text { Liquefaction }\end{array}$ & 65 & $\begin{array}{c}\text { Gasification } \\
\text { Combined } \\
\text { Cycle }\end{array}$ & 50 & $\begin{array}{l}\text { Advanced } \\
\text { Turbines }\end{array}$ & 181 & CCUS & 215 \\
\hline Heat Engines & 182 & $\begin{array}{l}\text { Combustion } \\
\text { Systems }\end{array}$ & 61 & $\begin{array}{l}\text { Pressurized } \\
\text { Fluid Bed }\end{array}$ & 17 & $\begin{array}{l}\text { Sequestra- } \\
\text { tion }\end{array}$ & 37 & STEP & 16 \\
\hline $\begin{array}{l}\text { Magnetohy- } \\
\text { drodynamics }\end{array}$ & 234 & Heat Engines & 38 & $\begin{array}{c}\text { Advanced } \\
\text { Res. \& } \\
\text { Environ. }\end{array}$ & 34 & Fuels & 29 & $\begin{array}{c}\text { Transforma- } \\
\text { tional Coal } \\
\text { Pilots }\end{array}$ & 20 \\
\hline $\begin{array}{l}\text { Surface Coal } \\
\text { Gasification }\end{array}$ & 493 & $\begin{array}{l}\text { Magnetohy- } \\
\text { drodynamics }\end{array}$ & 73 & $\begin{array}{c}\text { Coal } \\
\text { Liquefaction }\end{array}$ & 10 & Fuel Cells & 58 & $\begin{array}{l}\text { NETL Coal } \\
\text { RD\&D }\end{array}$ & 37 \\
\hline Mining RD\&D & 195 & $\begin{array}{l}\text { Surface Coal } \\
\text { Gasification }\end{array}$ & 43 & $\begin{array}{c}\text { Steelmaking } \\
\text { Feedstock } \\
\text { Fuel Cells }\end{array}$ & $\begin{array}{l}10 \\
65\end{array}$ & $\begin{array}{l}\text { Advanced } \\
\text { Research }\end{array}$ & 33 & & \\
\hline Total* & 2,229 & & 436 & & 250 & & 472 & & 484 \\
\hline
\end{tabular}

\section{ECONOMIC AND JOB IMPACTS}

We assessed the impacts and benefits resulting from realized savings through 2000; reduced CAPEX; efficiency savings; clean coal technology exports; $\mathrm{SO}_{2}$ reductions; $\mathrm{NO}_{\mathrm{x}}$ reductions; $\mathrm{CO}_{2}$ reductions; public health; NETL operations; and jobs. NRC estimated that realized economic benefits through 2000 from the DOE coal RD\&D programs totaled approximately $\$ 7.3$ billion (2019 dollars) [8]. In addition, we estimate that, in 2019 dollars, excluding $\mathrm{CO}_{2}$ benefits, the benefits attributable to the DOE coal RD\&D program through 2019 totaled about $\$ 237$ billion (2019 dollars), including [9]:

1. The total savings through 2019 from reduced capital costs of new plants and control technologies for existing plants was approximately $\$ 7.6$ billion.

2. The cumulative fuel cost savings resulting from efficiency improvements through 2019 totaled about \$3 billion.

3. The cumulative U.S. clean coal technology export benefits through 2019 totaled approximately $\$ 42.6$ billion.

4. The environmental benefits of $\mathrm{SO}_{2}$ emissions reductions - Fig. 3 - through 2019 totaled about $\$ 68.5$ billion.

5. The environmental benefits in terms of $\mathrm{NO}_{\mathrm{x}}$ reductions - Fig. 4 - totaled $\$ 35.9$ billion.

6. Using the 2013 Interagency Working Group (IWG) social cost of carbon (SCC) estimate [10], the total estimated value of the $\mathrm{CO}_{2}$ captured by the Petro Nova
CCUS plant is about $\$ 0.2$ billion (2019 dollars). The implied monetized $\mathrm{CO}_{2}$ emissions savings from the Petra Nova plant and the high efficiency low emissions (HELE) plants totaled approximately $\$ 2.4$ billion.

7. The total public health benefits through 2019 totaled approximately $\$ 36.9$ billion.

8. The beneficial impacts of NETL operations, 20002109 , totaled $\$ 35$ billion.

We estimate that the jobs created over the period $2000-$ 2019 totaled approximately 1,572,000 - about 78,600/yr. The number of jobs created is important, but it is also important to disaggregate the employment generated into occupations and skills. The jobs generated will be disproportionately concentrated in fields related to the construction, energy, utilities, technology export, mining, industrial, and related sectors [11].

While numerous studies have found that government RD\&D is a classic public good and that the benefit-cost (BC) ratio of this RD\&D is high [12], there is little consensus on what this ratio is. Previous research has estimated RD\&D B-C ratios that range from 4-to-1 to 180-to-1 [13].

Substantial benefits have been realized by numerous companies in the private sector due to assistance from the DOE coal RD\&D program. These include Carpenter Technology Corporation, LumiShield Technologies, KW Associates, Harbison Walker, Liquid Ion Solutions, Boston Scientific Corporation, and Pyrochem Catalyst Corporation [14]. 

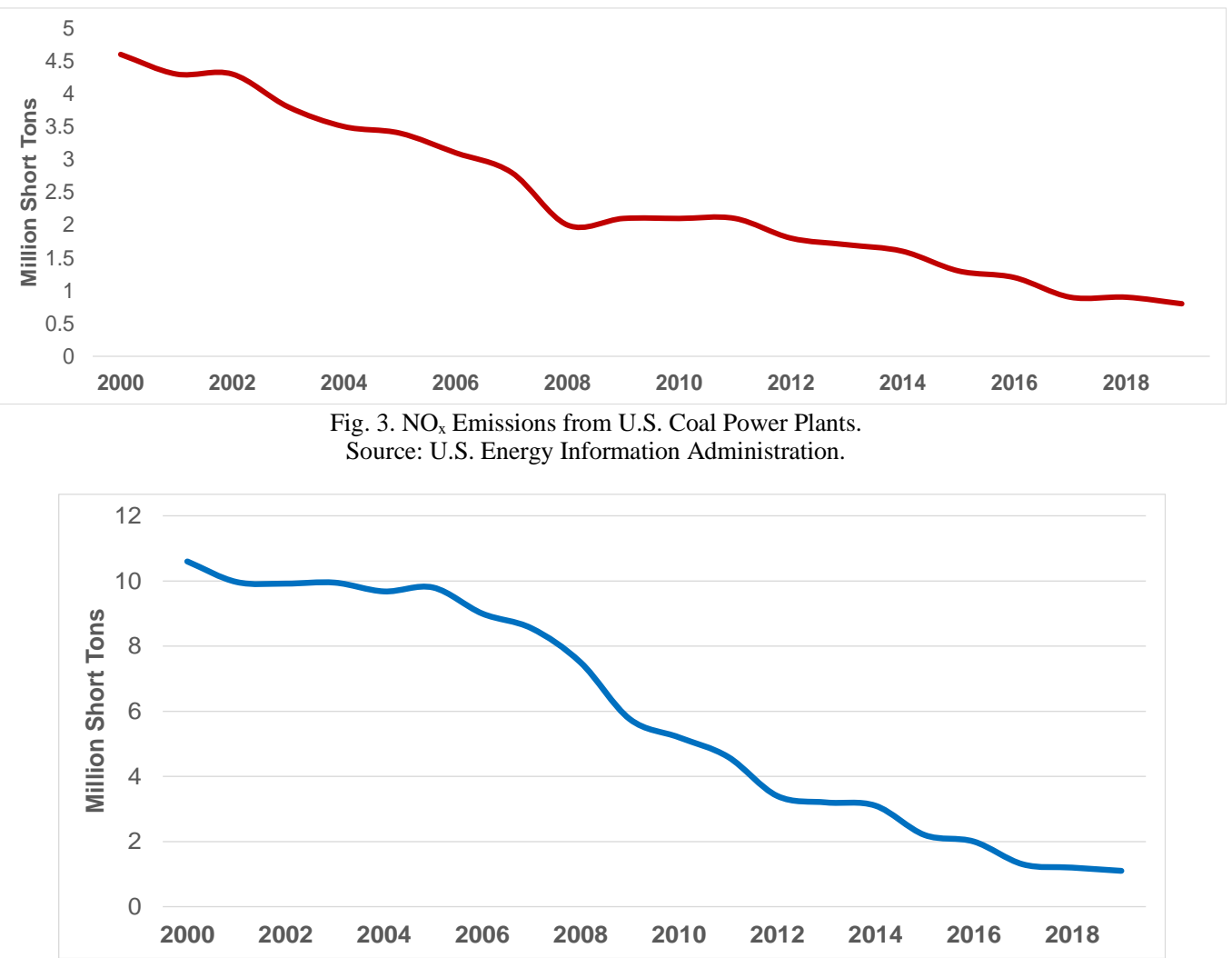

Fig. 4. $\mathrm{SO}_{2}$ Emissions from U.S. Coal Power Plants. Source: U.S. Energy Information Administration.

The DOE coal RD\&D program has significant economic, and job impacts on specific cities and regions throughout the U.S., including Pennsylvania and West Virginia. In addition, we estimated the jobs impacts on Reading, Pennsylvania, where Carpenter Technology is located. This success helped create a total of about 575 jobs (direct and indirect) in the Reading area and, absent these jobs, the unemployment rate in Reading would have been $5.3 \%$ instead of $5.0 \%$ - a meaningful difference [15].

\section{FINDINGS}

Table III and Fig. 5 show that the benefits of the DOE coal RD\&D program through 2019 total about $\$ 237$ billion (2019 dollars) - about $\$ 239$ billion including a monetized value for reduced $\mathrm{CO}_{2}$ emissions, and annual creation of nearly 79,000 jobs, or about 1.6 million cumulative jobs over the period 2000-2019. Thus, the impacts and benefits of the DOE coal RD\&D program through 2019 far exceed the costs $-\$ 28.6$ billion (2019 dollars). This implies a rough $\mathrm{B}-\mathrm{C}$ ratio of more than 8-to-1.

A B-C ratio above one is desirable and a ratio over 8-to-1 is extremely attractive. It is also reasonable when compared to $\mathrm{B}-\mathrm{C}$ ratios for other RD\&D programs. As noted, analyses of other RD\&D programs found $\mathrm{B}-\mathrm{C}$ ratios ranging from 4to-1 up to an incredible 180-to- 1 . On this basis, the DOE coal RD\&D program B-C ratio of 8-to1 is conservative. Further, a study of 15 leading economies estimated an overall B-C ratio for RD\&D of about 20-to-1 [16]. Thus, on this basis also the DOE coal RD\&D program B-C ratio of 8to1 is reasonable.

Knowledge benefits are scientific knowledge and useful technological concepts resulting from RD\&D that have not yet been commercialized but hold promise for future utilization or are useful in unintended applications. The DOE coal RD\&D program has yielded significant benefits in terms of important technological options and important additions to the stock of engineering and scientific knowledge in a number of fields and it facilitated numerous commercial spin-offs. We did not quantify knowledge benefits. Nevertheless, these are real and substantial and should be recognized as a key result of the program [17].

TABLE III: IMPACTS OF THE DOE COAL RD\&D PROGRAM THROUGH 2019

\begin{tabular}{cc}
\hline Category & $\begin{array}{c}\text { Impacts (billions of } 2019 \\
\text { dollars) }\end{array}$ \\
\hline Realized Savings Through 2000 & $\$ 7.3$ \\
Reduced CAPEX & $\$ 7.6$ \\
Efficiency Savings & $\$ 2.9$ \\
Clean Coal Technology Exports & $\$ 42.6$ \\
$\mathrm{SO}_{2}$ & $\$ 68.5$ \\
$\mathrm{NO}_{\mathrm{x}}$ & $\$ 35.9$ \\
$\mathrm{CO}_{2}$ & $42.1 \mathrm{Mt} *$ \\
Public Health & $\$ 36.9$ \\
NETL Operations & $\$ 35.0$ \\
Jobs & 78,600 jobs/yr.** \\
Total & $\$ 236.7$ \\
Total, including $\mathrm{CO}_{2}$ & $\$ 239.1$ \\
\hline
\end{tabular}

* Using the 2013 IWG SCC value of $\$ 52 /$ ton of $\mathrm{CO}_{2}$ (2019 dollars), we estimate that the implied $\mathrm{CO}_{2}$ emissions savings, 2008-2019, total approximately $\$ 2.4$ billion (2019 dollars).

**Annual average for the period 2008-2019.

Source: Management Information Services, Inc. 


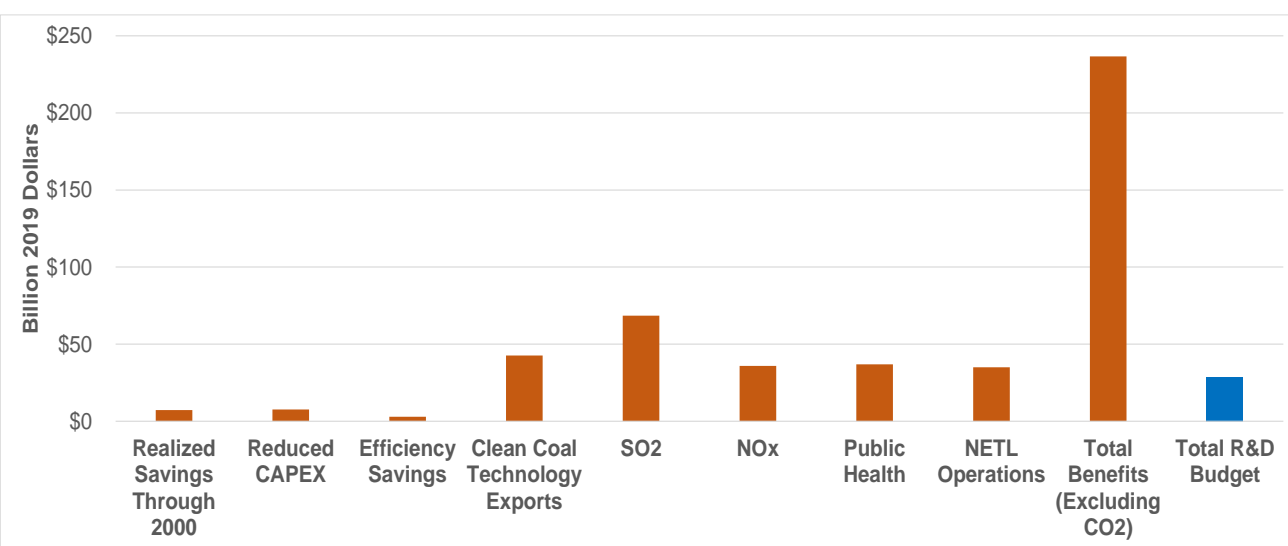

Fig. 5. Impacts, Benefits, \& Cost of the DOE Coal RD\&D Program Through 2019. Source: Management Information Services, Inc.

\section{CONCLUSIONS}

The DOE coal RD\&D program budget has been subject to wide variations over time, often over short periods. For example, in real terms:

- $\quad$ The budget declined 80\% 1980-1983;

- $\quad$ It declined $20 \%$ from 1986 to 1987 ;

- It declined 40\% from 1996 to 1997 ;

- It increased more than twofold 2000-2002;

- It declined more than 50\% 2009-2011.

Such fluctuations are not conducive to coherent, long term RD\&D. The budget has been relatively stable in real terms over about the past decade, but program funding priorities within the budget changed substantially over this period.

Large portions of the coal RD\&D program budgets were comprised of expenditures on technologies that were not successful. Subtracting expenditures on just three of these Coal Liquefaction, $\$ 4.9$ billion, Coal Gasification, $\$ 3.7$ billion, and Magnetohydro-dynamics, \$2.0 billion - which combined comprised more than $35 \%$ of the total DOE coal RD\&D budget through 2019, leaves a cumulative DOE coal RD\&D budget of $\$ 10.5$ billion. However, a portfolio approach must be used to assess RD\&D programs. Some DOE coal RD\&D programs are among DOE's most successful RD\&D programs, they have produced benefits that far exceed their costs, and the estimated benefits of DOE high-risk, high-payoff programs can greatly exceed their projected cost. Nevertheless, some RD\&D programs often have impacts that are minimal or are difficult to quantify.

The most important conclusion derived here is that the benefits of the DOE coal RD\&D program through 2019 -\$237 billion (2019 dollars) -- far exceed the costs -- \$28.6 billion (2019 dollars). This implies a rough B-C ratio of over 8-to-1. This is impressive: $\mathrm{B}-\mathrm{C}$ ratios above 2 or 3 are desirable, and ratios higher than that are very attractive. Some other energy RD\&D programs have purported B-C ratios much higher than this. However, upon close scrutiny many of these are of questionable validity.

The conclusion that the impacts and benefits of the DOE coal RD\&D program far exceed the costs is robust and is reasonable:

1) It is robust because the cost estimate is based on official published Federal government data, and many of the benefit estimates have been verified by independent studies
2) It is reasonable - and perhaps even conservative when compared to benefit-cost estimates for other RD\&D programs. Purported astronomical B-C ratios are simply not credible.

The number of jobs created over the period 2000-2019 totaled about 1.6 million - about 78,600/yr - and is large, and job creation is especially important in specific local areas and in specific sectors, industries, and occupations. These local job impacts can be of critical importance especially in the current environment of widespread job losses.

Relying on other measures, such as patents, papers published, or conference presentations, as criteria for RD\&D success can be inaccurate, misleading, and subject to conflict of interest. Finally, knowledge benefits can be significant. Indeed, the DOE coal RD\&D program has yielded benefits in terms of important technological options for potential application and additions to the stock of engineering and scientific knowledge in many fields. While these benefits are difficult to quantify, they are nevertheless real and should be recognized as an important result of the RD\&D program.

\section{RECOMMENDATIONS}

First, the most important recommendation derived here is that the future benefits of current DOE coal RD\&D programs must be forecast, monetized, and assessed against the forecast cost of the programs. Here we estimated the historical DOE coal RD\&D budget and the retrospective impacts of the RD\&D programs to date. However, the most relevant questions concern the future size and composition of the DOE coal RD\&D budget. Obviously, simply because the past program has produced impressive results is no guarantee that it will continue to do so [18].

The largest program in the 2020 DOE coal RD\&D budget is CCUS, receiving more than $44 \%$ of the total, followed by Advanced Energy Systems, 31\% [19]. Adding Transformational Coal Projects, 4\%, and STEP, 3\%, indicates that over $80 \%$ of the budget is devoted to RD\&D with benefits anticipated well into the future. This is the proper structure for an RD\&D program: It should focus on technologies of the future. In particular, CCUS is not only a current major focus of the DOE program but, to date, it is the third most generously funded coal RD\&D program even though funding for it did not begin until 2001. Policy- 
makers have realized that any ambitious decarbonization goals are not feasible without CCUS [20]. Notably, three of the major emphases in the DOE 2021 fossil energy budget request are i) utilization of coal and $\mathrm{CO}_{2}$ for the production of critical materials and products; ii) transformational $\mathrm{CO}_{2}$ capture technologies; and iii) $\mathrm{CO}_{2}$ storage [21].

DOE and the U.S. Congress are interested in determining the economic and jobs impacts of CCUS, and over the past three decades have expended $\$ 2.5$ billion on DOE CCUS RD\&D. CCUS is vital for the DOE coal RD\&D program: 1) It is a DOE greenhouse gas (GHG) reduction technology; 2) DOE has a long history and acknowledged expertise in CCUS; 3) it is a program that enjoys strong bipartisan support in Congress [22]; 4) it is a program that will likely be strongly supported well into the future; 5) when combined with EOR, it is economically viable.

DOE CCUS program funding requires justification, which must be derived from the forecast economic, environmental, and jobs benefits of the CCUS program. Here we estimated the $\mathrm{CO}_{2}$ emissions reduction benefits to date from the Petra Nova plant and the HELE plants [23]. However, these reductions have only just begun to accrue and the benefits from widespread CCUS and CCUS/EOR over the next several decades have to be estimated and evaluated. Thus, the economic, energy, environmental, and jobs impacts of future DOE-facilitated CCUS initiatives must be assessed. This research could provide estimates of the impacts that would result from the CCUS asset construction and operation and from the associated $\mathrm{CO}_{2} / \mathrm{EOR}$ oil production. It should estimate the economic and job impacts of CCUS capacity build-out and $\mathrm{CO}_{2}$-EOR oil production through 2050. In addition, the economic impacts of the 2018 45Q CCUS tax credits can be compared with the impacts of those proposed in 2017 and with other proposed CCUS tax credits and incentives.

Further, research has estimated that the DOE CCUS RD\&D program alone could create 14 to 16 million jobs. It also found that RD\&D is much more cost-effective than tax credits, and that the marginal impacts of the DOE RD\&D program are substantial [24]. Nevertheless, to maximize job creation both CCUS RD\&D and tax credits and need to be implemented in a coordinated manner, and these impacts need to be assessed.

Second, the job impacts of DOE programs are of critical importance and are especially relevant in the current environment where job losses and unemployment are at record levels not seen since the Great Depression of the 1930s. It is impossible to over-emphasize the importance of jobs and employment impacts. For example:

- Over the past two decades the DOE coal RD\&D program has generated a cumulative total of 1.6 million jobs - about 78,600/yr.

- Regional disaggregation is required of the jobs created, especially at the state level. The importance of estimating benefits to specific states and regions is obvious, for the debate at the state and regional level inevitably centers upon jobs. The number of jobs created is important, but it is also important to disaggregate employment generated into occupations and skills. Jobs created are across a wide spectrum in many industries and occupations, and research is required to estimate these impacts. The importance of jobs in some occupations is much greater than in others, and jobs impacts by sector, industry, and occupation/skills, including new and emerging occupations, must be estimated.

- Coal will continue to be important for U.S. electricity production [25]. Further, rapid expansion of coal retrofit CCUS, $\mathrm{CO}_{2} / \mathrm{EOR}, \mathrm{CO}_{2}$ pipelines, and associated infrastructure can facilitate the creation of new industries, increased industry sales and profits, increased GDP, millions of jobs, and expanded high skilled, well-paying employment opportunities. These have to be estimated and assessed.

- Research should be initiated on the potential jobs impacts of future CCUS retrofits. This should be based on appropriate assumptions regarding $\mathrm{CO}_{2}$ taxes and tax credits, industry requirements, deployment of CCUS technology, resource levels, EOR projects, and other relevant parameters.

Third, a portfolio approach must be used to assess DOE coal RD\&D benefits and costs - and, indeed such an approach is required to assess the benefits and costs of any energy R\&D program. As noted, some DOE coal RD\&D programs are among DOE's most successful RD\&D programs, they have produced benefits that far exceed their costs, and the benefits of DOE high-risk, high-payoff programs can greatly exceed their cost. On the other hand, other RD\&D programs produce impacts and benefits that are minimal or less certain. This is very important in evaluating the overall DOE RD\&D program, but it is not widely appreciated. Decades ago, no one knew which RD\&D programs would be successful and which would not. This is a basic fact of any RD\&D enterprise and will be as true in the future as in the past.

Finally, there is currently a widespread general perception concerning the disadvantages of fossil fuels - especially coal. This must be addressed by rigorous, credible research assessing the economic and job impacts the DOE coal RD\&D program - such as that provided here. Importantly, the findings reported here must be critiqued and compared to the benefits and costs of other types of energy, energy efficiency, and $\mathrm{CO}_{2}$ emissions reduction $\mathrm{RD} \& \mathrm{D}$ programs [26].

\section{REFERENCES}

[1] National Research Council, Energy Research at DOE: Was It Worth It? Committee on Benefits of DOE R\&D on Energy Efficiency and Fossil Energy, Commission on Engineering and Technical Systems, Washington, D.C.: National Academies Press, 2001.

[2] U.S. General Accounting Office, Fossil Fuel R\&D: Lessons Learned in the Clean Coal Technology Program, GAO-01-854T, June 12, 2001.

[3] Management Information Services, Inc., Benefits of Investments in Clean Coal Technology, prepared for American Coalition for Clean Coal Electricity, Washington, D.C., October 2009; Roger Bezdek and Robert Wendling, "The Return on Investment of the Clean Coa Technology Program in the USA," Energy Policy, March 2013, Vol. 54, pp. 104-112.

[4] U.S. Energy Research and Development Administration and U.S. Department of Energy, Congressional Budget Requests, FY 1976 FY 2020. 
[5] The implicit price deflator (IPD), compiled by the Bureau of Economic Analysis (BEA) of the U.S. Department of Commerce, is a by-product of the deflation of GDP and is derived as the ratio of current- to constant-dollar GDP (multiplied by 100). U.S. Bureau of Economic Analysis, "Implicit Price Deflator," https://www.bea.gov/help/faq/513.

[6] For example, although the FY 2001 and FY 2020 DOE coal RD\&D budgets were approximately equal at about $\$ 480$ million (2019 dollars), the technologies funded in each year were entirely different except for $\mathrm{CO} 2$ sequestration.

[7] The complete budget detail (in constant 2019 dollar) and analysis is given in Management Information Services, Inc., "A Retrospective Analysis of the Costs, Impacts, and Benefits of the U.S. Department of Energy Coal RD\&D Program," prepared for The U.S. Department of Energy, July 2020; http://misi-net.com/publications.html; pp. 42 61.

[8] National Research Council, Energy Research at DOE: Was It Worth It? Op. cit.

[9] Detailed discussion of these impacts in given in Management Information Services, Inc., "A Retrospective Analysis of the Costs, Impacts, and Benefits of the U.S. Department of Energy Coal RD\&D Program," op. cit., pp. 62-135.

[10] Interagency Working Group on Social Cost of Carbon, United States Government, "Technical Support Document: Technical Update of the Social Cost of Carbon for Regulatory Impact Analysis Under Executive Order 12866," May 2013.

[11] Management Information Services, Inc., "Analyzing and Estimating the Economic and Job Benefits of U.S. Coal," op. cit.; National Coal Council, "Harnessing Coal's Carbon Content to Advance the Economy, Environment, and Energy Security," June 2012; Bezdek and Wendling, "Economic, Environmental, and Job Impacts of Increased Efficiency in Existing Coal-Fired Power Plants," op. cit.; Southern States Energy Board, American Energy Security: Building a Bridge to Energy Independence and to a Sustainable Energy Future, Norcross, Georgia, July 2006; Roger H. Bezdek, "The Hydrogen Economy and Jobs of the Future," Renewable Energy and Environmental Sustainability, Vol. 4, No. 1 (2019).

[12] See Sean Pool and Jennifer Erickson, "The High Return on Investment for Publicly Funded Research, Center for American Progress, December 2012. Economists Charles Jones and John Williams of Stanford University, the National Bureau of Economic Research, and the Federal Reserve Bank of San Francisco found that the return on investment (ROI) for publicly funded RD\&D is somewhere between 30 percent and 100 percent, or more. Charles I. Jones and John C. Williams, "Too Much of a Good Thing? The Economics of Investment in R\&D," Journal of Economic Growth, Volume 5 (March 2000), pp. 65-85.

[13] Over the past decade, the DOE Office of Energy Efficiency and Renewable Energy (EE\&RE) supported a series of studies evaluating the impacts of its RD\&D programs, including photovoltaics, wind energy, vehicle combustion engines, advanced battery technologies for electric-drive vehicles, geothermal energy, HVAC (heating, ventilation and air conditioning), water heating, and appliance technologies. The combined results of these six RD\&D studies show that, for the EERE RD\&D investments evaluated, the aggregate B-C ratio was 33-to-1, and ranged from 4-to-1 to 180-to-1. Research on Federal investment in genomics RD\&D reported a B-C ratio of 178to-1.Jeff Dowd, "Aggregate Economic Return on Investment in the U.S. DOE, U.S. Department of Energy, Office of Energy Efficiency and Renewable Energy, October 2017; Rosalie Ruegg, Alan C. O'Connor, and Ross J. Loomis, "Evaluating Realized Impacts of DOE/EERE R\&D Programs," TIA Consulting Inc. and RTI International, August 2014, https://energy.gov/sites/prod/files/ 2015/05/f22/evaluatingrealized_rd_mpacts 9-22-14.pdf; Michae Gallaher, Troy Scott, Zachary Oliver, Kyle Clark-Sutton, and Benjamin Anderson, "Benefit-Cost Evaluation of U.S. Department of Energy Investment in HVAC, Water Heating, and Appliance Technologies," RTI International, September 2017; Albert N. Link, Alan C. O'Connor, Troy J. Scott, Sara E. Casey, Ross J. Loomis, and J. Lynn Davis, "Benefit-Cost Evaluation of U.S. DOE Investment in Energy Storage Technologies for Hybrid and Electric Cars and Trucks," RTI International, December 2013; A. O'Connor, R. Loomis, and F. Braun, "Retrospective Benefit-Cost Evaluation of DOE Investments in Photovoltaic Energy Systems," RTI International, August 2010; M. Gallaher, A. Rogozhin, and J. Petrusa, "Retrospective Benefit-Cost Analysis of U.S. DOE's Geothermal Technologies R\&D Program Investments,” RTI International, August 2010; Tom Pelsoci, "Retrospective Benefit-Cost Evaluation of U.S DOE Wind Energy R\&D Program: Impact of Selected Energy Technology Investments," Delta Research Co., June 2010; Al Link,
"Retrospective Benefit-Cost Evaluation of U.S. DOE Vehicle Combustion Engine R\&D Program: Impacts of a Cluster of Energy Technologies," prepared for the U.S. Department of Energy, May 2010. Research on Federal investment in genomics RD\&D reported a B-C ratio of 178-to-1. "The Impact of Genomics on the U.S. Economy," Battelle Technology Partnership, prepared for United for Medical Research, June 2013.

[14] See Carpenter Technology Corporation 2016 Form 10-K Annual Report, 2017; "NETL Technology For Safer, Cleaner Corrosion Protecting Metal Coatings Licensed by Pittsburgh Start-Up;"' https://netl.doe.gov/sites/default/files/netl-file/BDO15-

013_LumiShield\%20Success\%20Story.pdf; https:// www.energy.gov/fe/articles/netl-technology-safer-cleaner-corrosionprotecting-metal-coatings-licensed-pittsburgh; "NETL Issues Licenses For its Arc Position Sensing Technology," https://netl. doe.gov/sites/default/files/netl-file/BDO15-

012_KW\%20Success\%20Story.pdf; "ANH Refractories Becomes Harbison Walker International," Ceramic Industry Magazine, January 19, 2015; NETL "Licenses Transformational Technology For Carbon Dioxide Capture," https://netl.doe.gov/sites/ default/files/netlfile/BDO16001_Liquid\%20Ion\%20 Solutions\%20Success\% 20 Story.pdf; "Novel Platinum/Chromium Alloy for the Manufacture of Improved Coronary Stents," https://netl.doe.gov/ sites/default/files/2019-03/BDO12-004_Coronary\%20Stent.pdf;

"Pyrochem Catalysts for Diesel Fuel Reforming," https://netl.doe.gov/sites/ default/files/netl-file/BDO13008_Pyrochem\%20R\%26D\%20 success\% 20Story.pdf.

[15] Management Information Services, Inc., "A Retrospective Analysis of the Costs, Impacts, and Benefits of the U.S. Department of Energy Coal RD\&D Program,” op. cit.; http://misi-net.com/publications.html; pp. 141-144.

[16] Chris Coons, "R\&D is Essential For Boosting the American Economy," The Hill, July 11, 2017.

[17] See the discussion in National Research Council, Energy Research at DOE: Was It Worth It? Op. cit.

[18] As the cautionary warning on financial statement reads, "Past performance is no guarantee of future results."

[19] See Office of Chief Financial Officer, Department of Energy FY 2021 Congressional Budget Request, DOE/CF-0167, February 2020.

[20] For example, the UN states "If the world is to succeed in constraining $\mathrm{CO}_{2}$ emissions to levels consistent with a less than $2^{\circ} \mathrm{C}$ rise in global temperatures, then Carbon Capture and Storage (CCS) will need to contribute about one-sixth of needed $\mathrm{CO}_{2}$ emission reductions in 2050, and 14 percent of the cumulative emissions reductions between 2015 and 2050." United Nations Commission for Europe, "Carbon Capture and Storage: A Technological Challenge Already Solved," 2020. Similarly, the IEA found that CCUS is critical to reach climate goals. International Energy Agency, "Energy Technology Perspectives 2020," $\quad$ September 2020, https://www.iea.org/reports/energy-technology-perspectives-2020.

[21] Office of Chief Financial Officer, Department of Energy FY 2021 Congressional Budget Request, DOE/CF-0167, February 2020.

[22] For example, at the FY20 DOE Budget Hearing, Representative Greg Walden stated "I am encouraged by the work DOE is doing to support transformative breakthroughs in 'carbon free' fossil energy and carbon capture technologies." Opening Statement of Republican Leader Greg Walden, Subcommittee on Energy "The Fiscal Year 2020 DOE Budget," May 9, 2019. Further, Democrat Presidential nominee, Joe Biden, is on record as supporting CCUS.

[23] We also estimate that through 2019, the Petra Nova plant has created 2,840 total (direct plus indirect) jobs in Texas and cumulative local tax revenues of $\$ 9$ million, cumulative Texas tax revenues of $\$ 21$ million, and cumulative Federal tax revenues of $\$ 45$ million.

[24] Management Information Services, Inc., "Analyzing the Economic and Job Impacts of the DOE R\&D Program and CCS Tax Credits," prepared for the National Energy Technology Laboratory, DOE contract DE-FE 0025912, January 2018.

[25] U.S. Energy Information Administration, Annual Energy Outlook 2020, January 2020.

[26] A recent comparison of the economic and jobs impacts of CCUS compared to renewable energy alternatives is given in Management Information Services, Inc., "Use of the San Juan Generating Station to Develop Metrics to Compare Coal Fueled Power Plant Jobs Impacts to Those of Renewables," prepared for the U.S. Department of Energy, August 2020; http://misi-net.com/publications.html.

[27] National Research Council, Energy Research at DOE: Was It Worth It? Committee on Benefits of DOE R\&D on Energy Efficiency and Fossil Energy, Commission on Engineering and Technical Systems, Washington, D.C.: National Academies Press, 2001.

[28] Ibid. 
[29] U.S. General Accounting Office, Fossil Fuel R\&D: Lessons Learned in the Clean Coal Technology Program, GAO-01-854T, June 12, 2001.

[30] Frank Shaffer and Melissa Chan, Forecasting the Benefits of DOE Programs for Advanced Fossil-Fuel Electricity Generating Technologies: The EIA High Fossil Electricity Technology Case, National Energy Technology Laboratory, October 2002.

[31] U.S. Department of Energy, the Electric Power Research Institute, and the Coal Utilization Research Council, "Clean Coal Technology Roadmap," 2004; National Energy Technology Laboratory, "Clean Coal Technology Roadmap: CURC/EPRI/DOE Consensus Roadmap, Background Information," April 20, 2004.

[32] National Research Council, Prospective Evaluation of Applied Energy Research and Development at DOE (Phase One): A First Look, Committee on Prospective Benefits of DOE's Energy Efficiency and Fossil Energy R\&D Programs, Washington, D.C.: National Academies Press, 2005.

[33] Sales and Benefits of Technology from Clean Coal Demonstration Projects. National Energy Technology Laboratory, 2006.

[34] National, State, and Regional Economic and Environmental Impacts of NETL, report prepared by Lisa Phares, National Energy Technology Laboratory, Deborah Lange and Christopher Hendrickson, Carnegie Mellon University, and Randall Jackson and David Martinelli, West Virginia University, DOE/NETL-404.02.01, June 30, 2007; National, State, and Regional Economic and Environmental Impacts of NETL: Pennsylvania-West Virginia Region, U.S. Department of Energy, National Energy Technology Laboratory, September 2007..

[35] Management Information Services, Inc., Benefits of Investments in Clean Coal Technology, prepared for American Coalition for Clean Coal Electricity, Washington, D.C., October 2009; Roger Bezdek and Robert Wendling, "The Return on Investment of the Clean Coal Technology Program in the USA," Energy Policy, March 2013, Vol. 54, pp. 104-112.
[36] Randall Jackson, Amanda Krugh, Brian LaShier, and Ronald Munson, "National and State Economic Impact of NETL," West Virginia University, Regional Research Institute, October 2009.

[37] Randall Jackson, Amanda Krugh, Brian LaShier, and Ronald Munson, "National and State Economic Impact of NETL," West Virginia University, Regional Research Institute, October 2009.

[38] BBC Research and Consulting, Employment and Other Economic Benefits from Advanced Coal Electric Generation with Carbon Capture and Storage, report prepared for the Industrial Union Council, AFL-CIO; the International Brotherhood of Boilermakers, Iron Ship Builders, Blacksmiths, Forgers, and Helpers; the International Brotherhood of Electrical Workers; the United Mine Workers of America; and the American Coalition for Clean Coal Electricity, Denver, Colorado, February 2009.

[39] https://www.energy.gov/fe/about-us/benefits-research.

[40] Roger Bezdek and Robert Wendling, "Economic, Environmental, and Job Impacts of Increased Efficiency in Existing Coal-Fired Power Plants," Journal of Fusion Energy, Volume 32, Number 2 (April 2013), pp. 215-220.

[41] National Coal Council, Fossil Forward -- Revitalizing CCS, Washington, D.C., 2015.

[42] Union of Concerned Scientists, "Three Reasons Why Federal Energy R\&D is a Wise Investment," January 2017.

[43] National Energy Technology Laboratory, "Economic Impacts of $\begin{array}{llll}\text { NETL } & \text { United } & \text { States," } & 2018,\end{array}$ https://netl.doe.gov/sites/default/files/201905/National_Impact_Factsheet.pdf.

[44] Management Information Services, Inc. and Leonardo Technologies Inc., "Economic Impact Assessment of CCUS Retrofit of the Comanche Generating Station," prepared for the U.S. Department of Energy and the National Energy Technology Laboratory, June 2019.

[45] Leonardo Technologies, Inc., "Wyoming Carbon Capture, Utilization, and Storage (CCUS) Study," prepared for the United States Department of Energy Office of Fossil Energy, August 2020. 